\title{
Influence of burnout syndrome on the quality of life of nursing professionals: quantitative study
}

\author{
Influência da síndrome de burnout na qualidade de vida de profissionais da enfermagem: estudo quantitativo \\ Influencia del síndrome de burnout en la calidad de vida de profesionales de enfermería: estudio cuantitativo
}

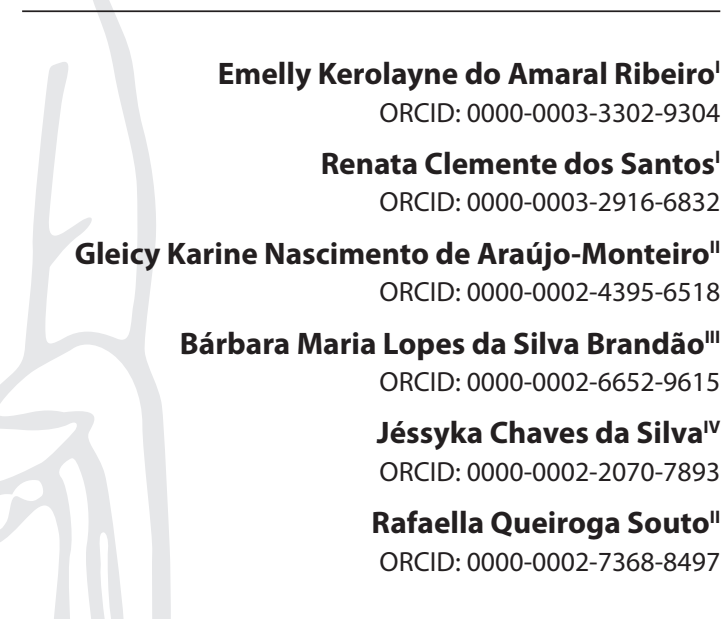

'Centro UNIFACISA. Campina Grande, Paraíba, Brazil. "Universidade Federal da Paraíba. João Pessoa, Paraíba, Brazil. "'Universidade Federal de Pernambuco. Recife, Pernambuco, Brazil. "Universidade Estadual da Paraíba. Campina Grande, Paraíba, Brazil.

How to cite this article: Ribeiro EKA, Santos RC, Araújo-Monteiro GKN, Brandão BMLS, Silva JC, Souto RQ. Influence of burnout syndrome on the quality of life of nursing professionals: quantitative study. Rev Bras Enferm. 2021;74(Suppl 3):e20200298. doi: http://dx.doi.org/10.1590/0034-7167-2020-0298

Corresponding author:

Renata Clemente dos Santos E-mail: renata.clemente@hotmail.com

EDITOR IN CHIEF: Antonio José de Almeida Filho ASSOCIATE EDITOR: Ana Fátima Fernandes

Approval: 09-15-2020

\section{ABSTRACT}

Objective: To estimate the prevalence and factors associated with the burnout syndrome and quality of life among nursing professionals. Methods: Cross-sectional, analytical study, developed with 83 professionals in emergency care units in the city of Campina Grande-PB. A questionnaire was used to characterize the sample, the Maslach Burnout Inventory scale and the SF-36. Data was analyzed using descriptive and inferential statistics. Results: Most professionals showed low professional effectiveness $(78.3 ; n=65)$, average depersonalization $(53.0 \% ; n=44)$ and average emotional exhaustion $(55.4 \% ; n=46)$. There was a statistical difference between the scores of the syndrome and the pain $(p=0.03)$, vitality $(p=0.04)$ and social aspect $(p=0.03)$; significant correlation between the syndrome and vitality $(p<0.001)$, mental health $(p=0.01)$ and general quality of life $(p=0.04)$. Conclusion: The burnout syndrome has an influence on the outcome of quality of life of nursing professionals, being more prevalent among professionals with older age, high income and among nurses.

Descriptors: Burnout, Professional; Quality of Life; Syndrome; Nursing; Burnout, Psychological.

\section{RESUMO}

Objetivo: Estimar a prevalência e fatores associados à síndrome de burnout e qualidade de vida entre profissionais de enfermagem. Métodos: Estudo transversal, analítico, desenvolvido com 83 profissionais nas unidades de pronto atendimento do município de Campina GrandePB. Utilizou-se um questionário para caracterização da amostra, a escala Maslach Burnout Inventory e a SF-36. Os dados foram analisados mediante estatística descritiva e inferencial. Resultados: A maioria dos profissionais apresentou baixa eficácia profissional $(78,3 ; n=65)$, média despersonalização $(53,0 \% ; n=44)$ e média exaustão emocional $(55,4 \% ; n=46)$. Houve diferença estatística entre os escores da síndrome e da dor $(p=0,03)$, vitalidade $(p=0,04)$ e aspecto social $(p=0,03)$; correlação significativa entre a síndrome e a vitalidade $(p<0,001)$, saúde mental $(p=0,01)$ e qualidade de vida geral $(p=0,04)$. Conclusão: A síndrome de burnout apresenta influência no desfecho de qualidade de vida de profissionais da enfermagem, sendo mais prevalente entre profissionais com idade mais avançada, renda elevada e entre enfermeiros.

Descritores: Esgotamento Profissional; Qualidade de Vida; Síndrome; Enfermagem; Esgotamento Psicológico.

\section{RESUMEN}

Objetivo: Estimar la prevalencia y factores relacionados al síndrome de Burnout y calidad de vida entre profesionales de enfermería. Métodos: Estudio transversal, analítico, desarrollado con 83 profesionales en las atenciones de emergencia de Campina Grande-PB. Utilizó un cuestionario para caracterización de la muestra, la escala Maslach Burnout Inventory y la SF-36. Los datos analizados mediante estadística descriptiva e inferencial. Resultados: La mayoría de los profesionales presentó baja eficacia profesional $(78,3 ; n=65)$, mediana despersonalización $(53,0 \% ; n=44)$ y mediana agotamiento emocional $(55,4 \% ; n=46)$. Hubo diferencia estadística entre los escores del síndrome y del dolor $(p=0,03)$, vitalidad $(p=0,04)$ y aspecto social $(p=0,03)$; correlación significativa entre el síndrome y la vitalidad $(p<0,001)$, salud mental $(p=0,01)$ y calidad de vida general $(p=0,04)$. Conclusión: El síndrome de Burnout presenta influencia en el desfecho de calidad de vida de profesionales de la enfermería, siendo más predominante entre profesionales con edad más avanzada, renta elevada y entre enfermeros.

Descriptores: Agotamiento Profesional; Calidad de Vida; Síndrome; Enfermería; Agotamiento Psicológico. 


\section{INTRODUCTION}

Work is considered to be a source of personal achievement, strengthening interpersonal relationships, satisfying basic human needs and survival ${ }^{(1)}$. The uniqueness of health work is related to the specificities of the service provided, as it is a relationship between beings with complex needs. In the health service environment, the professional is commonly exposed to dealing with suffering and is challenged to develop political, ethical and technical mechanisms to manage their own suffering under the circumstances ${ }^{(2)}$. In this sense, the work process among health professionals is constituted by potentially stressful conditions, which can directly affect their health as well as the quality of care provided to users ${ }^{(3)}$.

Occupational stress manifests itself as a public health problem, characterized by injury of a multifactorial cause, resulting from the relationship between the worker and his environment ${ }^{(4)}$. Nevertheless, continuous exposure to occupational stressful events can cause burnout syndrome (BS), mental and behavioral disorders ${ }^{(5)}$.

BS, in turn, is configured as a series of physical and psychosocial symptoms, among which are fatigue, difficulty in interpersonal relationships, bad mood, irritability, low productivity and absenteeism ${ }^{(6)}$. Occupational stress, although triggered by multi-causal factors, is closely associated with chronic stress in the workplace and has three dimensions: emotional exhaustion, depersonalization and low professional achievement ${ }^{(7)}$.

Emotional exhaustion comprises a lack of energy and a feeling of exhaustion by emotional resources, while depersonalization involves a state of emotional insensitivity, which implies anxiety, self-centered behavior, demotivation and irritability ${ }^{(6)}$. With regard to low professional achievement, there is a tendency to negative self-assessment of the work process, professional dissatisfaction and distance from other professionals ${ }^{(8)}$.

The practice of nursing in critical patient care environments can be a source of occupational stress since the professional experiences stressful situations, whether due to an exhaustive workday or unhealthy working conditions, inadequate personal dimensioning and highly complex assistance ${ }^{(9)}$. A study carried out with nursing professionals in Iran estimated that $36 \%$ had symptoms of BS; however, in Brazil, it was found that this percentage was $14.3 \%{ }^{(9-10)}$ in research developed in Minas Gerais ${ }^{(11)}$. Different working conditions, specific assistance and sociodemographic characteristics are factors that influence and justify the disparities in prevalence rates between different countries.

Considering that this problem affects the health of the worker, it can be said that it also affects the quality of life, which translates into a broad concept of personal perception about the sociocultural context, expectations, desires and their interrelationship with the community and work ${ }^{(12)}$. Thus, evaluating the quality of life of nurses enables reflection on the proposal of measures for their health, which will reflect on the quality of care, satisfaction with life, reduction of stress levels ${ }^{(13)}$ and prevention of BS.

In addition, investigating the relationship between BS and quality of life indices can provide contributions to changes in nursing care, construction of critical reflective processes among managers and professionals and feasibility in adopting strategies that mitigate work overload and dissatisfaction, providing thus, satisfactory levels of mental health in health institutions.

\section{OBJECTIVE}

To estimate the prevalence and factors associated with the burnout syndrome and quality of life among nursing professionals.

\section{METHODS}

\section{Ethical aspects}

The ethical assumptions determined in Resolution 466/12 of the National Health Council clarify that, for the development of research with human beings, it is necessary to appraise an Ethics in Research Committee (ERC). Thus, this study obtained a favorable opinion from the ERC of the Center for Higher Education and Development (CHED).

\section{Study design, period and location}

This is a cross-sectional, analytical study with a quantitative approach, carried out in the two Emergency Care Units in the municipality of Campina Grande-PB, developed from January to March 2018. The study was guided by the Strengthening the Reporting of Observational Studies in tool Epidemiology (STROBE).

\section{Population or sample; inclusion and exclusion criteria}

The research population was composed of nursing professionals (technicians and nurses) of both sexes and any age, working in the two emergency care units in the municipality of Campina Grande-PB. The sample was non-probabilistic for accessibility, totalling 83 employees.

Nursing professionals over 18 years old, who had worked in the service for at least six months working in the emergency care unit, were included. Those who were absent from the work environment at the time of data collection and those who were diagnosed with BS less than a year ago were excluded - this criterion was adopted to minimize the possibility of emotional destabilization related to unpleasant memories by the professional.

\section{Study protocol}

Three instruments were used for data collection: a questionnaire to characterize the sample prepared by the research team, the scale "BS Evaluation - Maslach Burnout Inventory (MBI)" and the Brazilian version of the SF-36 quality of life questionnaire, applied in the sequence described.

The $\mathrm{BS}$ rating scale was developed and validated by Christina Maslach. It is a self-assessment scale, in which the subject is asked to evaluate, in seven possibilities, how often he feels a set of feelings expressed in sentences ${ }^{(14)}$. The version that was applied in this study contains 22 items, being used for health-care professionals (HCP).

The SF-36, on the other hand, is a quality of life assessment questionnaire composed of 36 questions that assess eight different domains: functional capacity; physical aspects; pain; general health status; vitality; social aspects; emotional aspects; and mental health ${ }^{(15)}$.

Previous contact was made with the unit's coordination to perform data collection at a time determined by the service. The professionals were approached and invited to participate in the 
research, and the data collection took place at a time and place convenient to the employee.

The analysis of the studied outcome was carried out only at the end of data collection, in order to preserve the anonymity of the participants. In addition, researchers behave around the place of service, to present the results of the research and to clarify measures for the prevention of health problems in nursing workers.

\section{Analysis of results and statistics}

The BS scale assessment followed the precepts of its applicability, identifying three conceptual dimensions: emotional exhaustion, professional fulfilment and depersonalization. The definition of BS was characterized by a low score for professional effectiveness and a high score for emotional exhaustion and depersonalization. This variable was determined as a study dependent variable.

The independent variables were extracted from the sample characterization questionnaire (sex, age, marital status, income, number of children, type of residence and professional category), from the facets of quality of life (functional capacity, limitations due to physical aspects, pain, general health status, vitality, social aspects, limitations due to emotional aspects and mental health) and general quality of life (low and high quality of life).

Each facet of quality of life was determined in a score from 0 to 100 , and the determination of low and high quality of life was performed by the median cut of the score; and the overall quality of life was determined by the weighted average of the eight facets.

The data were tabulated in Microsoft Excel and analyzed in SPSS, version 25.0, in which they received descriptive statistical treatment through relative and absolute frequencies. The inferential analysis took place between the sample characterization data and the scale domains using Pearson's chi-square test or Fisher's exact test, Spearman's correlation test and Mann-Whitney comparison test, with 0.05 being the value of $p$ adopted for statistical significance. Since the distribution shows a tendency towards non-normality of the data, the non-parametric test was chosen, determined by the Kolmogorov-Smirnov test.

\section{RESULTS}

Table 1 shows the relationship between sociodemographic data and BS. It is observed that the syndrome predominated among older individuals $(15 \% ; n=6)$, women $(15.1 \% ; n=11)$, nurses $(17.1 \%$; $\mathrm{n}=7)$, who do not have relationship (19.5\%; $n=8)$, have children $(23.1 \% ; n=6)$ and receive more than one salary $(14.3 \% ; n=8)$.

The analysis of the categories evaluated in BS according to their levels is shown in Table 2 , and it is possible to verify that most professionals had low professional effectiveness (78.3; $n=65)$, average depersonalization ( $53 \% ; n=44)$ and average emotional exhaustion $(55.4 \% ; n=46)$.

The BS comparison analysis was performed with the classification of each quality of life domain (Table 3). As it is a non-normal distribution, data regarding the median and interquartile range are being displayed, identifying that there is a statistically significant difference between the scores of the syndrome and the median of the domains of quality of life related to pain $(p=0.03)$, vitality $(p=0.04)$ and social aspect $(p=0.03)$.
Table 1 - Association of sociodemographic characteristics with burnout syndrome among respondents, Campina Grande, Paraíba, Brazil, 2018 (N=83)

\begin{tabular}{|c|c|c|c|}
\hline \multirow[b]{2}{*}{ Variables } & \multicolumn{3}{|c|}{ Burnout syndrome } \\
\hline & $\begin{array}{c}\text { With } \\
\text { syndrome } \\
\text { n (\%) }\end{array}$ & $\begin{array}{c}\text { Without } \\
\text { syndrome } \\
\text { n (\%) }\end{array}$ & $\underset{\text { value* }}{p}$ \\
\hline \multicolumn{4}{|l|}{ Age } \\
\hline Less than or equal to 37 years & $6(14.0)$ & $37(86.0)$ & \multirow{2}{*}{$0.892^{*}$} \\
\hline Older than 37 years & $6(15.0)$ & $34(85.0)$ & \\
\hline \multicolumn{4}{|l|}{ Sex } \\
\hline Female & $11(15.1)$ & $62(84.9)$ & \multirow{2}{*}{$0.557^{* *}$} \\
\hline Male & $1(10.0)$ & $9(90.0)$ & \\
\hline \multicolumn{4}{|l|}{ Graduation } \\
\hline Nursing technician & $5(11.9)$ & $37(88.1)$ & \multirow{2}{*}{$0.503^{*}$} \\
\hline Nurse & $7(17.1)$ & 34 (82.9) & \\
\hline \multicolumn{4}{|l|}{ Marital status } \\
\hline In a relationship & $4(9.5)$ & $38(90.5)$ & \multirow{2}{*}{$0.196^{*}$} \\
\hline Single & $8(19.5)$ & $33(80.5)$ & \\
\hline \multicolumn{4}{|l|}{ With children } \\
\hline Yes & $6(11.1)$ & $48(88.9)$ & \multirow{2}{*}{$0.190^{* *}$} \\
\hline No & $6(23.1)$ & $20(76.9)$ & \\
\hline \multicolumn{4}{|l|}{ Income } \\
\hline Up to 1 salary & $3(12.0)$ & $22(88.0)$ & \multirow[t]{2}{*}{$0.543^{* *}$} \\
\hline Greater than 1 salary & $8(14.3)$ & $48(85.7)$ & \\
\hline
\end{tabular}

Table 2 - Distribution of burnout syndrome categories according to their levels, Campina Grande, Paraíba, Brazil, 2018 (N = 83)

\begin{tabular}{lccc}
\hline Variables & $\begin{array}{c}\text { Low } \\
\mathbf{n}(\%)\end{array}$ & $\begin{array}{c}\text { Medium } \\
\mathbf{n}(\%)\end{array}$ & $\begin{array}{c}\text { High } \\
\mathbf{n}(\%)\end{array}$ \\
\hline Professional effectiveness & $65(78.3)$ & $17(20.5)$ & $1(1.2)$ \\
Depersonalization & $23(27.7)$ & $44(53.0)$ & $16(19.3)$ \\
Emotional exhaustion & $20(24.1)$ & $46(55.4)$ & $17(20.5)$ \\
\hline
\end{tabular}

Table 3 - Comparison of quality of life domains with the burnout syndrome score among participants, Campina Grande, Paraíba, Brazil, 2018

\begin{tabular}{|c|c|c|c|}
\hline \multirow{2}{*}{ Variables } & \multicolumn{3}{|c|}{ Burnout syndrome score } \\
\hline & Median & Interquartile range & $p$ value* \\
\hline \multicolumn{4}{|l|}{ Functional capacity } \\
\hline Low functional capacity & 21.1 & \multirow{2}{*}{$18.3-22.0$} & \multirow{2}{*}{0.38} \\
\hline High functional capacity & 20.0 & & \\
\hline \multicolumn{4}{|l|}{ Physical aspect } \\
\hline Low physical aspect & 20.0 & \multirow{2}{*}{$18.3-22.0$} & \multirow{2}{*}{0.77} \\
\hline High physical aspect & 20.0 & & \\
\hline \multicolumn{4}{|l|}{ Pain } \\
\hline Light pain & 20.6 & \multirow{2}{*}{$18.3-22.0$} & \multirow{2}{*}{0.03} \\
\hline Heavy pain & 19.6 & & \\
\hline \multicolumn{4}{|l|}{ General health status } \\
\hline Low general health & 20.00 & \multirow{2}{*}{$18.3-22.0$} & \multirow{2}{*}{0.85} \\
\hline High general health & 20.0 & & \\
\hline \multicolumn{4}{|l|}{ Vitality } \\
\hline Low vitality & 20.3 & \multirow{2}{*}{$18.3-22.0$} & \multirow{2}{*}{0.04} \\
\hline High vitality & 19.3 & & \\
\hline \multicolumn{4}{|l|}{ Social aspect } \\
\hline Low social aspect & 20.6 & \multirow{2}{*}{$18.3-22.0$} & \multirow{2}{*}{0.03} \\
\hline High social aspect & 19.3 & & \\
\hline \multicolumn{4}{|l|}{ Emotional aspect } \\
\hline Low emotional aspect & 20.6 & \multirow{2}{*}{$18.3-22.0$} & \multirow{2}{*}{0.06} \\
\hline High emotional aspect & 19.8 & & \\
\hline \multicolumn{4}{|l|}{ Mental health } \\
\hline Low mental health & 20.6 & \multirow{2}{*}{$18.3-22.0$} & \multirow{2}{*}{0.09} \\
\hline High mental health & 19.8 & & \\
\hline \multicolumn{4}{|l|}{ Quality of life } \\
\hline High quality of life & 20.6 & \multirow{2}{*}{$18.3-22.0$} & \multirow{2}{*}{0.14} \\
\hline Low quality of life & 20.0 & & \\
\hline
\end{tabular}


Table 4 - Correlation between the quality of life domains and the burnout syndrome score of the interviewees, Campina Grande, Paraíba, Brazil, 2018

\begin{tabular}{lcc}
\hline \multirow{2}{*}{ Variables } & \multicolumn{2}{c}{$\begin{array}{c}\text { Burnout syndrome score } \\
\text { Correlation coefficient }\end{array}$} \\
& $\boldsymbol{p}$ value* \\
\hline Functional capacity & -0.149 & 0.21 \\
Physical limitations & -0.101 & 0.40 \\
Pain & -0.209 & 0.07 \\
General health status & -0.044 & 0.71 \\
Vitality & -0.353 & $<0.00$ \\
Aspects social & -0.216 & 0.06 \\
Limitations due to emotional aspects & -0.049 & 0.68 \\
Mental health & -0.279 & 0.01 \\
Quality of life & -0.234 & 0.04 \\
\hline Note: ${ }^{*}$ Spearman's correlation test. & &
\end{tabular}

When correlating the domain score data related to quality of life with the syndrome score, it was found that there is a negative correlation between the variables, so that the higher the BS score, the lower the participants' quality of life. The correlation was statistically significant between the syndrome with vitality $(p<0.001)$, mental health $(p=0.01)$ and quality of life $(p=0.04)$.

\section{DISCUSSION}

The sociodemographic profile of the investigated population corroborated other studies that describe nursing as a predominantly female workforce, with children and with some type of relationship ${ }^{(16-19)}$.

BS is more common in females, as shown by a study in São Paulo( ${ }^{(9)}$, in which $16 \%$ of participating nurses were classified with BS. In another study, carried out in a medium-sized municipality in Minas Gerais, in the Primary Health Care units, a higher prevalence of female professionals was also identified ${ }^{(20)}$. The data of the present study agree with those evidenced in a research ${ }^{(21)}$ developed in the state of São Paulo, in which the majority of nursing professionals who were part of the sample were female (92\%), married (50\%) and with children (35\%).

Regarding the age of people who were classified as BS, a study carried out in a large university hospital in the city of São Paulo shows that the age group in which BS was higher is between 22 and 29 years old ${ }^{(9)}$; in another study in the interior of the state of $\mathrm{SP}$, a greater number of young adults working in different Intensive Care Units who had this syndrome was identified ${ }^{(22)}$.This relationship can be justified by the length of professional practice, suggesting, therefore, that younger professionals were more mentally burdened because they were less experienced and more insecure ${ }^{(23)}$.

The present study shows that exhaustion and depersonalization data showed higher percentages among nurses when compared to technicians. Supporting this result, a study carried out in two Psychosocial Care Centers (CAPS) located in the interior of Piauí showed that, regarding professional exhaustion, nurses (66.67\%) were the ones who suffered the most in relation to nursing technicians $(33,33 \%)$; however, when it comes to depersonalization, only $16.67 \%$ of both categories showed this result ${ }^{(23)}$.

The literature has presented BS as a common problem among nursing professionals, regardless of their specialty ${ }^{(9,20,24-25)}$. There was a prevalence of the syndrome among $14.5 \%$ of the sample's professionals, diverging from a study carried out with Mexican nurses, which registered the occurrence of the phenomenon in $34.6 \%$ of them ${ }^{(26)}$; however, the data ratify a national survey of nurses in an intensive care unit in which $14.3 \%$ had $\mathrm{BS}^{(9)}$.

Regarding the assessment of the syndrome according to the levels of the categories, most professionals showed low efficacy, as well as an average level of depersonalization and exhaustion. Given the predominance of average levels, it is clear that participants who have not yet been classified with BS are close to developing it.

The results of a meta-analysis demonstrate the prevalence of high exhaustion and depersonalization, as well as low professional achievement among nurses ${ }^{(27)}$. In the research carried out in Minas Gerais, nursing workers showed low levels of emotional exhaustion and depersonalization and moderate levels of job satisfaction $^{(11)}$. These scores can be justified by the precariousness of the work condition, since the nursing professional faces a reality of exhaustive hours, resulting in high rates of job abandonment, decreased quality of care and increased errors ${ }^{(9,28)}$.

In the evaluation of BS compared to the domains of quality of life, it was verified how much one phenomenon affects the other, with a correlation between the domains of quality of life (such as vitality, mental health and quality of life) with BS. In this study, some of these domains were related to BS, in line with other national and international investigations ${ }^{(29-30)}$.

With regard to pain, a review study observed the relationship between burnout and this variable, in which the syndrome is characterized as a risk factor for hospitalizations for musculoskeletal disorders. Among the types of pain, headache, neck-shoulder pain and low back pain are more present in the symptoms and, contextualizing with the public under discussion, who remains in the same position for several hours or experiences critical stress situations, it is inevitable its interference in the levels of quality of life and psychological well-being ${ }^{(31)}$.

Vitality consists of the individual's perception of energy levels and fatigue for daily activities ${ }^{(32)}$. Observing that this domain had low levels and was related to BS, it is clear that the equivalent symptoms, such as tiredness and demotivation, are included in the three dimensions of the syndrome. Consequently, there may be a decrease in work productivity, absenteeism and changes in the physical and mental health of nurses ${ }^{(33)}$.

The social aspect of quality of life was also related to BS; and, although this condition is relevant to the work environment, its outcomes interfere in the personal lives of nursing professionals ${ }^{(29)}$. In a meta-analysis review, the authors found that positive affects and social factors were associated with burnout, however an effective social support network, inside and outside work, contributes to coping with the syndrome, reduces levels of tension, anxiety and stress, as well as strengthening the resilience of these workers ${ }^{(34)}$.

The BS exhibited a negative correlation with the mental health domain of the interviewees, pointing out that the highest scores of the syndrome are in those individuals who have more fragility in mental health. This data converges with those of a study carried out with health professionals, in which mental health influenced the highest scores of the syndrome ${ }^{(35)}$.

The installation of BS favors the emergence of diseases that affect mental health, with the presence of symptoms such as fatigue, tiredness, changes in sleep, irritability, isolation, even pathologies such as anxiety, mood disorders and depression ${ }^{(29,35)}$. 
These changes hinder the ability to cope with situations of work stress, directly interfering in the quality of life ${ }^{(36)}$.

In this context, it appears that stress is aggravated by BS, negatively influencing the perception of the workplace, leading to trauma, dissatisfaction and demotivation in the performance of their function ${ }^{(35-36)}$. This data confirms the results exposed in international studies, as in Greece ${ }^{(36)}$, China ${ }^{(37)}$ e Portugal ${ }^{(38)}$.

Investigative studies of the impacts of BS on the quality of life of nursing professionals are relevant, since this professional team offers care that enables the constant experience of episodes of stress and psychological suffering, when dealing with multiple emergency situations, accidents deaths, deaths and overload of duties ${ }^{(36)}$.

\section{Study limitations}

The overload of nurses' duties was considered a limitation of the study, as it interferes with the time available for these professionals to carry out the research, requiring greater availability for the researcher to find them again in order to obtain the data.

\section{Contributions to the area of Nursing, Health or Public Policy}

Understanding the relationship between BS and nurses' quality of life makes it possible to identify the impacts that work activity has on the professional's performance, physical and mental health, as well as analyzing the factors that most strongly interfere in the quality of life of this individual. In addition, this understanding supports the development of strategies to prevent constant stress situations in professional practice, aiming to avoid the onset of the syndrome and contribute to the quality of life.

\section{CONCLUSION}

BS predominated among older professionals, women, nurses, unrelated, who have children and receive a higher income. The syndrome interferes with the quality of life of these professionals, causing a greater impact in the domains of vitality, pain, social aspect and mental health. Furthermore, it is possible to point out that the higher the BS, the lower the quality of life of the participants.

\section{REFERENCES}

1. Nobre DFR, Rabiais ICM, Ribeiro PCPSV, Seabra PRC. Burnout assessment in nurses from a general emergency service. Rev Bras Enferm. 2019;72(6):1457-63. doi: 10.1590/0034-7167-2017-0870

2. Aciole GG, Pedro MJ. [On the health of those who work in health: reviewing affinities between work psychodynamics and collective health]. Saúde Debate. 2019;43(120):194-206. doi: 10.1590/0103-1104201912015 Portuguese.

3. Carvalho DRS, Querido AIF, Tomás CC, Gomes JMF, Cordeiro MSS. A saúde mental dos enfermeiros: um estudo preliminar. Rev Port Enferm Saúde Mental. 2019;1(21):47-53. doi: 10.19131/rpesm.0237

4. Llapa-Rodriguez EO, Oliveira JKA, Lopes Neto D, Gois CFL, Campos MPA, Mattos MCT. Occupational stress in nursing personnel. Rev Enferm UERJ. 2018;26:e19404. doi: 10.12957/reuerj.2018.19404

5. Parola V, Coelho A, Cardoso D, Sandgren A, Apóstolo J. Prevalence of burnout in health professionals working in palliative care: a systematic review. JBI Database System Rev Implement Rep. 2017;15(7):1905-33. doi: 10.11124/JBISRIR-2016-003309

6. Paiva LC, Canário ACG, China ELCP, Gonçalves AK. Burnout syndrome in health-care professionals in a university hospital. Clinics. 2017;72(5):305-9. doi: 10.6061/clinics/2017(05)08

7. Cruz SP, Abellán MV. Professional burnout, stress and job satisfaction of nursing staff at a university hospital. Rev Latino-Am Enfermagem. 2015;23(3):543-52. doi: 10.1590/0104-1169.0284.2586

8. Vidotti V, Ribeiro RP, Galdino MJQ, Martins JT. Burnout Syndrome and shift work among the nursing staff. Rev Latino-Am Enfermagem. 2018;26:e3022. doi: 10.1590/1518-8345.2550.3022

9. Vasconcelos EM, Martino MMF. Predictors of burnout syndrome in intensive care nurses. Rev Gaúcha Enferm. 2017;38(4):e65354. doi: 10.1590/1983-1447.2017.04.65354

10. Rezaei S, Karami MB, Hajizadeh M, Soroush A, Nouri B. Prevalence of burnout among nurses in Iran: a systematic review and meta-analysis. Int Nurs Rev. 2018;65(3):361-9. doi: 10.1111/inr.12426

11. Dutra HS, Gomes PAL, Garcia RN, Oliveira HC, Freitas SC, Guirardello EB. [Burnout among nursing professionals in hospitals in Brazil]. Rev Cuid. 2018;10(1):e585. doi: 10.15649/cuidarte.v10i1.585 Portuguese.

12. Marques-Duarte MS, Pureza DY. Association between job satisfaction and workers' quality of life in a public maternity hospital in the far north of Brazil. Rev Bras Saúde Mater Infant. 2019;19(3):733-43. doi: 10.1590/1806-93042019000300013

13. Kowitlawkul Y, Yap SF, Makabe S, Chan S, Takagai J, Tam WWS, et al. Investigating nurses' quality of life and work life balance statuses in Singapore. Int Nurs Rev. 2018;66(1):61-9. doi: 10.1111/inr.12457

14. Maslach C, Goldberg J. Prevention of burnout: new perspectives. Appl Prev Psychol. 1998;7:63-74. doi: 10.1016/S0962-1849(98)80022-X

15. Ware JE, Sherbourne CD. The MOS 36-item short health survey (SF-36). I. Conceptual framework and item selection. Med Care. 1992;30(6):473-83. doi: 10.1097/00005650-199206000-00002

16. Almeida PA, Mazzaia MC. Nursing appointment in mental health: experience of nurses of the network. Rev Bras Enferm. 2018;71(suppl 5):2154-60. doi: 10.1590/0034-7167-2017-0678 
17. Carvalho DP, Rocha LP, Pinho EC, Tomaschewski-Barlem JG, Barlem ELD, Goulart LS. Workloads and burnout of nursing workers. Rev Bras Enferm. 2019;72(6):1435-41. doi: 10.1590/0034-7167-2017-0659

18. Park J-S, Lee E-H, Park N-R, Choi YH. Mental health of nurses working at a government-designated hospital during a MERS-CoV Outbreak: a cross-sectional study. Arch Psychiatr Nurs. 2018;32(1):2-6. doi: 10.1016/j.apnu.2017.09.006

19. Faria S, Queirós C, Borges E, Abreu M. Saúde mental dos enfermeiros: contributos do burnout e engagement no trabalho. Rev Port Enferm Saúde Mental. 2019;22:9-18. doi: 10.19131/rpesm.0258

20. Lima AS, Farah BF, Bustamante-Teixeira MT. [Analysis of the prevalence of burnout syndrome in professionals of primary health care]. Trab Educ Saúde. 2017;16(1). doi: 10.1590/1981-7746-sol00099 Portuguese.

21. Trettene AS, Ferreira JAF, Mutro MEG, Tabaquim LM, Razera NPR. Estresse em profissionais de enfermagem atuantes em Unidades de Pronto Atendimento. Bol Acad Paul Psicol [Internet]. 2016 [cited 2020 Feb 20];36(91):243-61. Available from: http://pepsic.bvsalud.org/pdf/bapp/ v36n91/v36n91a02.pdf

22. Fernandes LS, Nitsche MJT, Godoy I. Association between burnout syndrome, harmful use of alcohol and smoking in nursing in the ICU of a university hospital. Ciênc Saúde Colet. 2018;23(1):203-14. doi: 10.1590/1413-81232018231.05612015

23. Silva LO, Soares LS, Fernandes ADBF, Rocha RC, Silva GRF. Burnout syndrome in professional workers from psychosocial care centers: a descriptive study. Rev Enferm Atual Derm. 2018;85(1):37-43. doi: 10.31011/1519-339X.2018a18n85.04

24. Adriaenssens J, Gucht V, Maes S. Determinants and prevalence of burnout in emergency nurses: a systematic review of 25 years of research. Int J Nurs Stud. 2015;52(2):649-61. doi: 10.1016/j.ijnurstu.2014.11.004

25. Albedín L, Gómez JL, Fuente GAC, Cañadas GR, Luis CS, Aguyo R. Prevalencia Bayesiana y niveles de burnout em enfermería de urgencias. una revision sistemática. Rev Latino-Am Psicol. 2016;48(2):137-45. doi: 10.1016/j.rlp.2015.05.004

26. Rizo-Baeza M, Mendiola-Infante SV, Sepehri A, Palazón-Bru A, Gil-Guillén VF, Cortés-Castell E. Burnout syndrome in nurses working in palliative care units: an analysis of associated factors. J Nurs Manag. 2018;26:19-25. doi: 10.1111/jonm.12506

27. Gómez-Urquiza JL, Fuente-Solana El, Albendín-García L, Vargas-Pecino C, Ortega-Campos EM, Cañadas-De la Fuente GA. Prevalence of burnout syndrome in emergency nurses: a meta-analysis. Crit Care Nurse. 2017;37(5):e1-e9. doi: 10.4037/ccn2017508

28. Oliveira EB, Gallasch CH, Silva Jr PPA, Oliveira AVR, Valério RL, Dias LBS. Occupational stress and burnout in nurses of an emergency service: the organization of work. Rev Enferm UERJ. 2017;25:28842. doi: 10.12957/reuerj.2017.28842

29. Vidotti V, Martins JT, Galdino MJQ, Ribeiro RP, Robazzi MLCC. Burnout syndrome, occupational stress and quality of life among nursing workers. Enferm Glob. 2019;18(3):344-76. doi: 10.6018/eglobal.18.3.325961

30. Asante JO, Li JE, Liao J, Huang YX, Hao YT. The relationship between psychosocial risk factors, burnout and quality of life among primary healthcare workers in rural Guangdong province: a cross-sectional study. BMC Health Serv Res. 2019;19:447. doi: 10.1186/ s12913-019-4278-8

31. Salvagioni DAJ, Melanda FN, Mesas AE, Gonzalez AD, Gabani FL, Andrade SM. Physical, psychological and occupational consequences of job burnout: a systematic review of prospective studies. PLoS One. 2017;12(10):e0185781. doi: 10.1371/journal.pone.0185781

32. Fraga MSR, Calvetti PU, Lazzarotto AR. A qualidade de vida dos profissionais da enfermagem que atuam no centro cirúrgico. Rev Depart Ciênc Hum. 2019;53:251-60. doi: 10.17058/barbaroi.v1i53.12986

33. Teixeira GS, Silveira RCP, Mininel VA, Moraes JT, Ribeiro IKS. Quality of life at work and occupational stress of nursing in an emergency care unit. Texto Contexto Enferm. 2019;28:e20180298. doi: 10.1590/1980-265X-TCE-2018-0298

34. Zhang YY, Zhang C, Han XR, Li W, Wang YL. Determinants of compassion satisfaction, compassion fatigue and burnout in nursing: a correlative meta-analysis. Medicine. 2018;97(26):e11086. doi: 10.1097/md.0000000000011086

35. Anjos JM, Picanço CM, Lopes LRR, Assis YI, Tapparelli YDA, Falcão LS. Qualidade de vida e síndrome de burnout em residentes multiprofissionais em área de saúde. C\&D Rev Eletron FAINOR. 2020;13(1):27-40. doi: 10.11602/1984-4271.2020.13.1.3

36. Sarafis $P$, Rousaki E, Tsounis A, Malliarou M, Lahana L, Bamidis $P$, et al. The impact of occupational stress on nurses' caring behaviors and their health related quality of life. BMC Nurs. 2016;15(56):1-9. doi: 10.1186/s12912-016-0178-y

37. Yu H, Jiang A, Shen J. Prevalence and predictors of compassion fatigue, burnout and compassion satisfaction among oncology nurses: a cross-sectional survey. Int J Nurs Stud. 2016;57:28-38. doi: 10.1016/j.jpurstu.2016.01.012

38. Duarte J, Pinto-Gouveia J. Empathy and feelings of guilt experienced by nurses: a cross-sectional study of their role in burnout and compassion fatigue symptoms. Appl Nurs Res. 2017;35:42-47. doi: 10.1016/j.apnr.2017.02.006 